\title{
VARIABILITY OF OLD SWEET CHERRIES FOUND IN SLOVAK REGIONS AND THEIR PRESERVATION
}

\author{
Michaela Benková ${ }^{1, \#}$, Iveta Čičová ${ }^{1}$, Daniela Benedikova ${ }^{1}$, Lubomir Mendel ${ }^{1}$, \\ and Miroslav Glasa ${ }^{2}$ \\ ${ }^{1}$ National Agriculture and Food Centre, Research Institute of Plant Production Piešt'any, Bratislavska cesta 122, \\ 92168 Piešt'any, SLOVAK REPUBLIC \\ ${ }^{2}$ Institute of Virology, Biomedical Research Center, Slovak Academy of Sciences, Dúbravská cesta 9, \\ 84505 Bratislava, SLOVAK REPUBLIC \\ \# Corresponding author, benkova@vurv.sk
}

Communicated by Edite Kaufmane

\begin{abstract}
The work is focused on the evaluation of variability of morphological and pomological characteristics of several old sweet cherries (Prunus avium L.) that were found in different Slovak regions. The experimental work has been performed during two years, 2014 and 2015. The following characteristics according to the descriptor list of subgenus Cerasus were evaluated - period of flowering and ripening, morphological characteristics of the flowers, fruit size, fruit weight, and quality parameters. The results showed high variability of evaluated accessions. From the 13 surveyed localities, the most valuable accessions were found in the locality Horni Streda - places Čachtice, Krakovany, Nitra, and Brdárka. During the collecting expeditions, 170 accessions of sweet cherry, with fruit of the different quality were found. The most interesting accessions were grafted onto rootstocks with different intensity of growth (Prunus avium L., Prunus mahaleb L., and 'Gisela5'). Some of the selected cherry accessions can be used for commercial growing after tests, while some of them can be used only for collection of genetic resources and as potential genitors in breeding programmes.
\end{abstract}

Key words: accessions, evaluation, Prunus avium, variability.

\section{INTRODUCTION}

Sweet cherry (Prunus avium L.) belongs to the Rosaceae family and is one of the most important fruit crops within the temperate regions of the world (Imtiyaz et al., 2013). Cherries have a higher calorific value than apples and are as rich in protein and sugars. In addition, carotene and folic acid concentrations are fairly high. The fruit is also a rich source of minerals like potassium, calcium, magnesium, iron, and zinc (Randhawa, 1991). Cherries in Slovakia are a traditional fruit used in the past and today are also very popular. In the past, several regions of Slovakia have been known for thrived fruit species and perhaps those plantings can still be found remaining today. An interesting situation is the occurrence of old cherry trees with age around 80-90 years. The quality and taste of old cultivars is irreplaceable, and therefore, the maintenance of old native trees of those species is justified, both for the preservation of cultural heritage and as part of biodiversity conservation.

The second half of the $20^{\text {th }}$ century and the first decade of the present one marked an enormous qualitative progression in sweet cherry breeding (Sansavini and Lugli, 2008). A large number of new sweet cherry cultivars with valuable pomological and economic characteristics were established, including self-fertile ones. The great advance in the development of genomics has led to improvement of the biotechnologies and molecular technologies, which undoubtedly have exerted a favourable effect on the breeding programmes by accelerating the breeding process and guaranteeing better success (Iezzoni et al., 2010; Zhivondov, 2011). In the last 30 years, over 500 new cultivars of sweet cherry and over 200 cultivars of sour cherry were created in the world. The largest number of new cultivars of sweet cherry was created in Ukraine, followed by USA, Russia, Romania, Canada, France, Italy, and Hungary (Milatovič and Nikolič, 2011). At present in Slovakia, there are no breeding programmes for any fruit species. Several European countries lead breeding programmes for fruit species with more than 50-year history and have achieved interesting objectives and results, such as in Romania (Budan et al., 2009), Hungary (Apostol, 2008; Hrotkó, 2008), Czech Republic (Blažkova, 1996), and Germany (Fischer et al., 2004). Hjalmarsson et al. (2008) studied the adaptation of some foreign plum and cherry cultivars in Sweden. 
The complete descriptions of cherry cultivars are very important for further use.

In Europe, many descriptions of sweet cherries have been made. Perez-Sanchez et al. (2008) refers to thirty-one traditional cultivars of Prunus avium L., Prunus $\times$ gondouinii Rehd., and Prunus cerasus L. from Central-Western Spain, which were surveyed and characterised agro-morphologically. A total of 37 descriptors were used to describe flowers, leaves, fruits over three consecutive years. This work is an important step in the conservation of genetic cherry resources in the province of Salamanca (Spain). The assessment of morpho-physiological diversity for one hundred and forty-six sweet cherry (Prunus avium) cultivars, originating from different countries and maintained in an $e x$ situ Gene Bank collection in Greece was carried out. Data on thirty-five traits, describing phenology, plant morphology, and yield and fruit quality were recorded over three years and analysed using PCA and hierarchical cluster analysis. The sweet cherry cultivars were classified into three main clusters, suggesting that the characterised sweet cherry collection had high potential for specific breeding goals (Ganopoulos et al., 2015). In Italy thirty four traditional accessions belonging to sweet cherry (Prunus avium L.), which were collected from different sites located in Tuscany, were characterised using a set of 47 agro-morphological traits established by the UPOV and IBPGR (Petruccelli et al., 2013). Significant phenotypic diversity was detected between traditional cherry accessions found in a small growing area (Tuscany, Italy), where cherry production represents a centuries-old tradition. In Portugal, nine sweet cherry and eight sour cherry varieties located in a germplasm bank at Fundćo, were studied from the viewpoint of morphological and qualitative characterisation. Most of them were autochthonous cultivars that had a high risk of extinction since at the present they are markedly minor varieties. Therefore, conservation of the autochthonous cultivars in the future is highly recommended (Rodrigues et al., 2008).

The goal of the present study was to evaluate variability of 60 cherry accessions found in three different localities in Slovakia through 11 characters and to select the best cherry sources for breeding use and for conservation in the Gene Bank of Slovak Republic.

\section{MATERIAL AND METHODS}

The occurrence of old cherry trees (Prunus avium L.) was surveyed in collecting expeditions between 2014 and 2015 in the territory of Slovakia. The Marhold and Hindák (1999) botanical classification was used. Topographical names were listed according to tourist maps (1: 50 000). Results of the monitoring and collection of plant genetic resources were processed in the central database of Gene Bank of SR GRISS. For this purpose, the software packages MS Office 2013, map software "Google Earth" collection sites, photo documentation and graphics software (Zoner) were used. A
Garmin Oregon GPS device 600 was used to record the coordinates of mapping locations.

The descriptors list for cherry (Schmidt et al., 1985) was used for basic description of trees, flowers, leaves, and fruits. For the characterisation of cherry fruit accessions, eleven fruit characters were selected. Of these, five traits were statistically analysed: fruit size (weight — WGHT (in grams), length - FLEN (in mm), width - FWIT (in mm), thickness - FTHI (in mm), and pedicel length — PLEN (in $\mathrm{mm}$ ). For all fruit characters 10 fruits from each accessions were investigated. The results were processed using the statistical package Statistica 8.0 (Statsoft, Inc., Tulsa, USA). Significant differences between samples were assessed by the Tukey's HSD test. Relationships between evaluation indicators were examined using the Pearson's correlation coefficient.

For regeneration, the collected cherry samples were grafted on standard rootstocks (Pr. mahaleb and 'Gisela 5') registered in Slovakia. For each accession, 10 pieces of rootstock were grafted.

\section{RESULTS}

Cherry samples were collected in three Slovak locations: Brdárka, Čachtice, and Krakovany (Fig. 1, Table 1).

Of the three surveyed sites, the largest occurrence of old cherry trees was recorded in locality Brdárka, which is located in the mountain range of Slovenské Rudohorie. This locality has rather unique characteristics. Wider surroundings are included among the botanically important areas. The village has a favourable position thanks to its special status in the context of the biological diversity of fruit species. The village has about 4000 cherry trees, which represent a minimum of about 50 different accessions. The vast



Fig. 1. Map of Slovakia with locations of sampled cherries

Table 1

GPS COORDINATES OF SURVEYED LOCALITIES

\begin{tabular}{c|c|c|c}
\hline No. & Locality & GPS & Altitude (m) \\
\hline 1 & Brdárka & N $48^{\circ} 45^{\prime} 57.00^{\prime \prime}$ & 566 \\
& & E $20^{\circ} 20^{\prime} 2.40^{\prime \prime}$ & \\
2 & Čachtice & N $48^{\circ} 40^{\prime} 48.50^{\prime \prime}$ & 175 \\
& & E 17'49'11.20" & \\
3 & Krakovany & N $48^{\circ} 36^{\prime} 52.70^{\prime \prime}$ & 157 \\
& & E $17^{\circ} 45^{\prime} 36.20^{\prime \prime}$ &
\end{tabular}


majority of trees are old and in a state of serious danger particularly due to lack of care and maintenance.

Locality Krakovany is located in western Slovakia, $8 \mathrm{~km}$ from the city Piešt'any. The altitude is around $175 \mathrm{~m}$ above sea level. There is an old alley of cherry trees planted along the Očkov channel that was used for irrigation of agricultural crops. The age of trees is about 60 to 70 years, and presently their health status is very poor, due to neglect.

The cherry alley of trees in locality Čachtice creates a $3 \mathrm{~km}$ link between the villages Horná Streda and Čachtice in western Slovakia. The time of tree planting can be estimated by tree age, which was considered to be over 80 years, based on stem diameter. Trees of large-fruited accessions and small fruit cherry accessions were identified. These accessions can be used as seed rootstocks and can be further integrated in rootstock trials.

Altogether 60 collected cherry accessions were evaluated with 11 morphological and phenological characters. Data (mean, maximum, minimum and coefficient of variation $\mathrm{CV} \%$ ) on the five quantitative characters is presented in Table 2. Fruit weight differed between locations and ranged from $3.7 \mathrm{~g}$ in Brdárka to $8.9 \mathrm{~g}$ in Krakovany. Fruit weight of accessions from Čachtice ranged from 4.0 to $7.7 \mathrm{~g}$, in locality Krakovany from 4.1 to $8.9 \mathrm{~g}$ and in locality Brdárka from 3.7 to $7.4 \mathrm{~g}$. In general, there was a large variation in fruit weight in the cherry germplasm studied. Local cultivars had smaller flowers, smaller and sweeter fruits with large endocarps, their appearance was less attractive, they had long peduncles, and they were more resistant to cracking.

The largest coefficient of variation for the trait fruit weight was recorded in locality Krakovany (29.49\%) and in
Brdárka $(21.27 \%)$, and the lowest coefficient of variation for traits fruit length $(5.26 \%)$, width and thickness $(5.61 \%)$ in Čachtice. Locality Čachtice significantly differed $(p<$ 0.01 ) in mean values of all characters (Fig. 2). Trees of large-fruited accessions occurred at this location. Analysis of fruits and according to the descriptions found in pomology books, they were considered to resemble the old late ripening German cultivar 'Hedelfinger'.

Within the localities, large differences between minimum and maximum width of fruit were observed, reaching 9.3 $\mathrm{mm}$ in Krakovany, and up to $12.0 \mathrm{~mm}$ in Brdirka.

Large differences were also observed between the minimum and the maximum pedicel length: $13.0 \mathrm{~mm}$ in Brdárka, 19.0 $\mathrm{mm}$ in Krakovany and $18.0 \mathrm{~mm}$ in Cachtice. The fruit pedicel length is not an important trait, but a longer pedicel makes harvest easier. Pedicel length varied in the selected accessions from $34 \mathrm{~mm}$ in Krakovany to $60 \mathrm{~mm}$ in Čachtice with mean $44.35 \mathrm{~mm}$ (Table 2). The old accessions had longer pedicle length.

Using Pearson's correlation coefficients showed significant strong relationships between fruit weight, length, width and thickness, as expected. The correlation between characters of the fruit size (fruit weight, length, width and thickness) and the pedicel length (Table 3 ) were statistically significant but rather weak (weight $r=0.37++$, length $r=0.29+$, width $r=0.29+$, and thickness $r=0.27+$ ).

\section{DISCUSSION}

Differences in fruit character of cherries have been studied by many authors. The fruit weight of 70 analysed cherry accessions from Iran ranged from 1.84 to $5.95 \mathrm{~g}$ with mean weight 3.82 g (Khadivi-Khub, 2014). Hegedus et al. (2013)

DESCRIPTIVE STATISTICAL ANALYSIS OF 5 MEASURED CHARACTERS IN THE 60 EVALUATED MONITORED CHERRY ACCESSIONS SAMPLED FROM THE 3 LOCATIONS.

\begin{tabular}{|c|c|c|c|c|c|c|}
\hline Localities & Parameters & WGHT (g) & FLEN (mm) & FWID (mm) & FTHI (mm) & PLEN (mm) \\
\hline \multirow[t]{5}{*}{ Brdárka $(\mathrm{n}=22)$} & Mean & 5.35 & 21.86 & 21.32 & 19.14 & 44.00 \\
\hline & Min. & 3.70 & 17.00 & 13.00 & 17.00 & 37.00 \\
\hline & Max. & 7.41 & 25.00 & 25.00 & 22.00 & 50.00 \\
\hline & Standard error & 0.24 & 0.50 & 0.71 & 0.34 & 0.75 \\
\hline & $\mathrm{CV}$ & 21.27 & 10.78 & 15.62 & 8.43 & 8.03 \\
\hline \multirow{4}{*}{ Krakovany $(\mathrm{n}=16)$} & Min. & 4.10 & 18.00 & 19.00 & 16.80 & 34.00 \\
\hline & Max. & 8.90 & 24.10 & 28.30 & 22.00 & 53.00 \\
\hline & Standard error & 0.35 & 0.43 & 0.57 & 0.32 & 1.30 \\
\hline & $\mathrm{CV}$ & 29.49 & 9.55 & 12.03 & 7.90 & 14.76 \\
\hline \multirow[t]{4}{*}{ Čachtice $(\mathrm{n}=22)$} & Mean & 6.69 & 22.88 & 25.13 & 21.31 & 49.00 \\
\hline & Min. & 4.00 & 21.00 & 22.00 & 18.00 & 42.00 \\
\hline & Standard error & 0.29 & 0.30 & 0.35 & 0.30 & 1.11 \\
\hline & $\mathrm{CV}$ & 17.14 & 5.26 & 5.61 & 5.61 & 9.10 \\
\hline
\end{tabular}

CV, coefficient of variation, \%; WGHT, fruit weight (g); FLEN, fruit length (mm); FWID, fruit width (mm), FTHI, fruit thickness (mm), PLEN, peduncle length $(\mathrm{mm})$ 


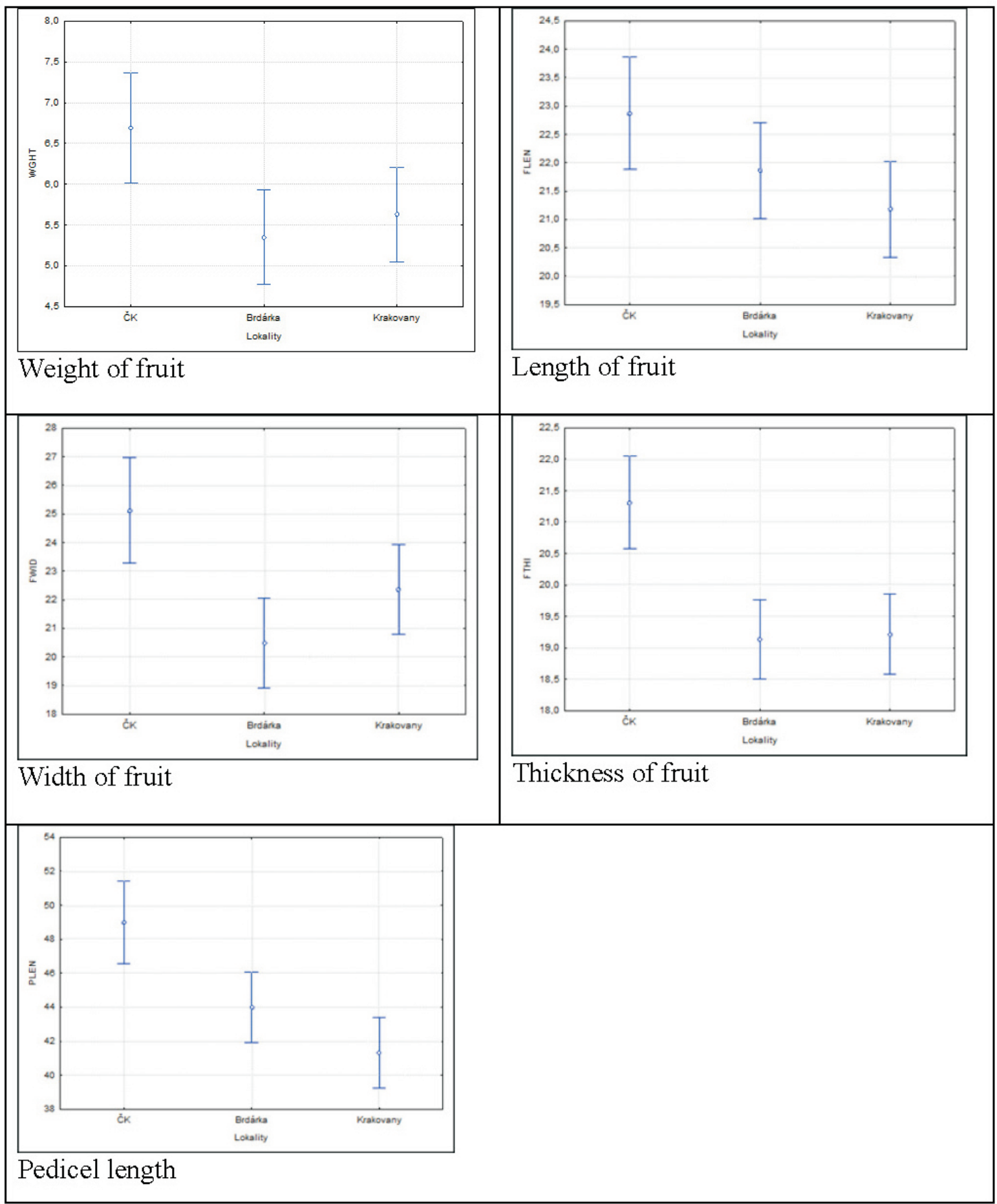

Fig. 2. Mean values of characteristics in three locations based on the Fisher's LSD test.

Table 3

CORRELATION MATRIX OF SELECTED CHARACTERISTICS OF SWEET CHERRY FRUIT

\begin{tabular}{l|c|c|c|c}
\hline & FLEN & FWID & FTHI & PLEN \\
\hline WGHT & $0.78^{++}$ & $0.85^{++}$ & $0.80^{++}$ & $0.37^{++}$ \\
FLEN & & $0.82^{++}$ & $0.79^{++}$ & $0.29^{+}$ \\
FWID & & & $0.81^{++}$ & $0.29^{+}$ \\
FTHI & & & & $0.27^{+}$
\end{tabular}

$\overline{{ }^{+} \text {significant at } 0.05}$ probability level, ${ }^{++}$significant at 0.01 probability level reported that Ukrainian sweet cherries had fruit weight with range of 5.10-8.33 g. According to Perez-Sanchez et al. (2008) there are clear differences between local and introduced genetically improved sweet cherry cultivars. Local cultivars had smaller flowers, smaller and sweeter fruits with large endocarps, their appearance was less attractive, they had long peduncles, and they were more resistant to cracking. Large-fruited accessions may be considered as perspective parents and for cultivation.

Fruit pedicel length is not among the most important pomological characteristics, but it contributes to the outer ap- 
pearance of the fruit sensory profile, and under certain conditions it makes mechanised harvesting easier (Zhivondov, 2011). Larger length of pedicle is better for machine harvesting of fruit regarding destruction of the fruit skin (Zhivondov, 2011). In that study fruit pedicel lengths ranged from 23.68 to $31.44 \mathrm{~mm}$. In Spanish cherries, Rodrigues et al. (2008) recorded stalk length in sweet cherry from 40 to $49 \mathrm{~mm}$, while Perez-Sanchez et al. (2008) recorded fruit stalks with length $33.40-48.10 \mathrm{~mm}$. According to Khadivi-Khub (2014), fruit stalk length (pedicel) ranged from 23.35 to $59.44 \mathrm{~mm}$ in sweet cherries with an average of $41.55 \mathrm{~mm}$. Significant positive correlation was found between fruit thickness and the fruit width $(r=0.974)$ in sweet cherry germplasm, maintained ex situ in the Gene bank collection in Greece (Ganopoulos et al., 2015). Similarly, Khadivi-Khub (2014) confirmed a very close correlation between fruit weight and fruit dimensions (length, width) and that fruit weight, stone weight and fruit dimensions did not show significant correlation with fruit stalk length.

\section{CONCLUSION}

During survey and collecting expeditions in 2014-2015, within the area of eastern and western Slovakia we found several interesting localities (Brdárka, Krakovany, and Čachtice) with old sweet cherry (Prunus avium L.) orchards. Of all three surveyed sites, the largest occurrence of old cherry trees was in locality Brdárka. Altogether 60 accessions of sweet cherry with fruit with large variability were found.

Collected cherries were evaluated based on five morphological characters. Data analysis of mean, maximum, minimum, and coefficient of variation values was conducted. The largest coefficient of variation for the trait fruit weight was recorded in the localities Krakovany and Brdárka. Fruit weight varied from $3.7 \mathrm{~g}$ in Brdárka to $8.9 \mathrm{~g}$ in Krakovany. The highest mean values of all investigated traits were recorded in the locality Čachtice.

The most interesting accessions have been grafted onto rootstocks with different growth vigour (Prunus avium L., Prunus mahaleb L., and 'Gisela5'). Based on the identified extent of variability of investigated traits at surveyed cherry accessions, estimated by coefficient of variation, accessions were selected that will be included in the field collection for conservation in the Gene Bank of Slovak Republic. These accessions can serve for further use in research and breeding.

\section{ACKNOWLEDGEMENTS}

This work was supported by the grant APVV-0174-12 from the Slovak Research and Development Agency and by COST FA1104 project.

\section{REFERENCES}

Apostol, J. (2008). New sweet and sour cherry selections in Hungary. Acta Horticult., 795, 75-77.

Blažková, J. (1996). Results of sweet cherry breeding at Holovousy from 1973 to 1993. Acta Horticult., 410, 393-398.

Budan, S., Braniste, N., Butac, M., Militaru, M., Dutu, I., Mazilu, C., Rovina, A. (2009). New achievements in fruit breeding at RIFG Pitesti. Proceedings of the Research Institute for Fruit Growing, Pitesti, Romania, 25, 9-11.

Fischer, M., Fischer, C. (2004). 75 years of tradition in classical Pillnitz fruit breeding: aims, results. Acta Horticult., 663, 699-706.

Gonçalves, B., J. Moutinho-Pereira, A., Santos, A. P., Silva, E. Bacelar, C., Correia, E. (2006). Scion-rootstock interaction affects the physiology and fruit quality 444 of sweet cherry. Tree Physiol., 26, 93-104.

Hegedus, A., Taller, D., Papp, N., Szikriszt, B., Ercisli, S., Halász, J., Stefanovits-Bányai, E. (2013). Fruit antioxidant capacity and self-incompatibility genotype of Ukrainian sweet cherry (Prunus avium L.) cultivars highlight their breeding prospects. Euphytica, 191, 153-164

Hjalmarsson, I., Trajkovski, V., Wallace, B. (2008). Adaptation of foreign plum and cherry varieties in Sweden. In: Proceedings of International Scientific Conference "Sustainable Fruit Growing: From Plant to Product", 28-31 May 2008, Jūrmala - Dobele, Latvia, pp. 141-148.

Hrotkó, K. (2008). Progress in cherry rootstocks research. Acta Horticult., 795, 171-178.

Iezzoni, A., Weebadde, C., Luby, J., Yue, C. Y., Peace, C. P., Bassil, N., McFerson, J. (2010). RosBRED: Enabling marker — assisted breeding in Rosaceae. Acta Horticult., 859, 389-394.

Imtiyaz, A., Khursheed, A., Bharty, K. (2013). Preserve and candy development of sweet cherry (Prunus avium L.). Int. J. Sci. Res. (IJSR). https://www.ijsr.net/archive/v5i7/NOV164709.pdf

Khadivi-Khub, A. (2014). Assessment of cultivated cherry germplasm in Iran by multivariate analysis. Trees, 28, 669-685

Marhold, K., Hindák, F. (1999). List of non-vascular and vascular plant of Slovakia. VEDA Bratislava, 1999, 689 pp. CD-ROM. http://ibot.sav.sk/checklist/ (in Slovakian).

Milatović, D., Nikolić, D. (2011). Cherry breeding in the world. In: Proceedings of the 3rd Conference "Innovations in Fruit Growing". Belgrade, pp. $21-48$.

Perez-Sanchez, R. Gómez-Sánchez, M. A., Morales-Corts, R. (2008). Agromorphological characterization of traditional Spanish sweet cherry (Prunus avium L.), sour cherry (Prunus cerasus L.) and duke cherry (Prunus $\times$ gondouinii Rehd.) cultivars. Spanish J. Agricult. Res., 6, 42-55.

Petruccelli R., Ganino T., Ciaccheric, L., Masellid, F., Mariottiaet, P. (2013). Phenotypic diversity of traditional cherry accessions present in the Tuscan region. Scientia Horticult., 150, 334-347

Randhawa, S. S. (1991). Cheries. In: Temperate Fruits. Mitra, S. K., Rathore, D. S., Bose, T. K. (eds.). Horticulture and Allied Publishers, Calcutta, pp. 304-343.

Rodrigues, L. C., Morales, M. R., Fernandes, A. J. B., Ortiz, J. M. (2008). Morphological characterization of sweet and sour cherry cultivars in a germplasm bank at Portugal. Genet. Resour. Crop Evol., 55, 593-601.

Sansavini, S., Lugli, S. (2008). Sweet cherry breeding programs in Europe and Asia. Acta Horticult., 795, 41-57.

Schmidt, H., Vittrup-Christensen, J., Watkins, R., Smith, R. A. (1985). Cherry Descriptors. International Board for Plant Genetic Resources, Rome.

Zhivondov, A. (2011). Comparative pomological study on new Bulgarian cherry cultivars. Proceedings of the $3^{\text {rd }}$ Conference "Innovations in Fruit Growing “. Belgrade, pp. 197-202. 


\section{SLOVĀKIJAS REĢIONOS ATRASTO VECO SALDO ĶIRŠU VARIABILITĀTE UN SAGLABĀŠANA}

Pētījuma mērkis bija vairākos Slovākijas reǵionos atrasto veco saldo kiršu (Prunus avium L.) morfoloǵisko un pomoloǵisko īpašỉbu novērtēšana. Eksperimentālais darbs veikts 2014. un 2015. gadā. Saskaņā ar Cerasus apakšǵints deskriptoriem tika noteiktas sekojošas pazìmes - ziedēšanas un augḷu gatavošanās laiks, ziedu morfoloğiskās īpašības, augḷu izmērs, svars un kvalitātes rādītāji. Novērtēto genotipu rezultātos atklājās augsta variabilitāte. No 13 apsekotajiem apvidiem vērtīgākie genotipi tika atrasti Horna Streda apvidū — vietās Čahtice, Krakovani, Nitra un Brdarka. Ekspedīcijās atrada 170 saldo k̦iršu genotipus ar dažādas kvalitātes augliem. Interesantākie genotipi tika potêti uz dažāda auguma potcelmiem (Prunus avium L., Prunus mahaleb L. un 'Gisela5'). Dažus no izdalītajiem kịšu genotipiem pēc pārbaudes varētu izmantot komerciālai audzēšanai, bet daži no tiem ievietojami ǵenētisko resursu kolekcijā tālākai izmantošanai pētījumos un selekcijā. 